\title{
STUDI KEPUASAN KONSUMEN MENGGUNAKAN EMPAT DIMENSI SERVQUAL PADA AREA PUBLIK TERMINAL 3 BANDARA CHANGI SINGAPURA
}

\author{
Andini Risfandini \\ Universitas Merdeka Malang \\ andini.risfandini@unmer.ac.id
}

\begin{abstract}
SERVQUAL is one of the model that is frequently used to measure customer satisfaction regarding the service quality. This study is using 4 dimensions of SERVQUAL to measure customer satisfaction about service quality in Changi Airport public area terminal 3 Singapore. The main objective of this study is to analyze the satisfaction level of Changi Airport's customers of service quality in the public area in Terminal 3. In order to achieve this main objective, the following sub objectives were set namely: (1)to investigate whether there is a gap between customer expectations and customer perception of service quality in Changi Airport public area terminal 3; (2) to identify the significant factors that affecting customer expectations of service quality in Changi Airport public area terminal 3; (3)To identify the significant factors that affecting customer perception of service quality in Changi Airport Public Area terminal 3. Data was collected using survey questionnaire with Likert scale, it was analyzed using SPSS 21 using descriptive statistics, two tailed test, and faktor analysis. .The factors that have significant impact on customers' expectations are assurance and security, comfort and convenience, safety and service, ambience and accessibility. While the customers' perception of service quality is influenced by convenience and service, comfort, ambience and cleanliness, safety, accessibility and security factors.
\end{abstract}

Keywords: SERVQUAL; service quality; customer perception; customer expectation

\begin{abstract}
Abstrak
SERVQUAL adalah salah satu model yang paling sering digunakan untuk mengukur kepuasan konsumen mengenai kualitas layanan. Studi ini menggunakan 4 dimensi SERVQUAL untuk mengukur kepuasan konsumen mengenai kualitas layanan pada area publik terminal 3 bandara Changi Singapura. Tujuan dari penelitian ini adalah untuk menganalisa tingkat kepuasan konsumen pada area publik terminal 3 bandara Changi Singapura. Untuk mencapai tujuan ini terdapat tiga hal yang harus dilakukan yakni: (1)Investigasi apakah terdapat gap antara ekspektasi dan persepsi konsumen akan kualitas layanan di area publik terminal 3 bandara Changi Singapura; (2) Identifikasi faktor yang mempengaruhi ekspektasi konsumen akan kualitas layanan di area publik terminal 3 bandara Changi Singapura. (3) Identifikasi faktor signifikan yang mempengaruhi persepsi konsumen akan kualitas layanan di area publik terminal 3 bandara Changi Singapura. Data dikumpulkan dengan menggunakan kuesioner menggunakan skala Likert, kemudian dianalisa dengan menggunakan SPSS 21 yang meliputi descriptive statistics, two tailed $t$-test dan faktor analysis. Faktor yang memiliki dampak signifikan pada harapan konsumen adalah jaminan dan keamanan, kenyamanan dan kemudahan, keamanan dan layanan, suasana dan aksesibilitas. Sedangkan persepsi konsumen mengenai kualitas layanan dipengaruhi oleh, kemudahan dan layanan, kenyamanan, suasana dan kebersihan, keamanan, aksesibilitas, dan faktor keselamatan
\end{abstract}

Kata kunci: SERVQUAL, kualitas layanan, persepsi konsumen, ekspektasi konsumen

\section{A. PENDAHULUAN}

Bandara sebagai bagian dari industri penerbangan memiliki peran penting dalam aktivitas ekonomi dunia untuk mendukung kemajuan ekonomi dengan mempromosikan aktivitas bisnis dan rekreasi. Bandara mendorong kesempatan bisnis internasional dan menciptakan kesempatan kerja bagi masyarakat lokal pada negara dimana bandara tersebut berlokasi (Senguttuvan, 2009). Industri penerbangan mendukung 63 juta pekerjaan pada tahun 2016 dan menjadi salah satu sumber pemasukan 
GDP sebesar 2.7 triliun dollar diseluruh dunia (IATA, 2016). Bandara Changi Singapura sebagai bagian dari industri penerbangan memiliki peran yang penting dan tidak dapat digantikan di Singapura untuk mendukung pertumbuhan ekonomi dan mendorong investasi dari investor internasional. Changi Airport Group (CAG) memiliki 1800 pekerja termasuk warga negara Singapura dan pekerja asing (Changi Airport Group, 2016).

Bandara Changi Singapura adalah salah satu bandara tersibuk dan memiliki koneksi terbanyak dengan bandara lain di seluruh dunia, melayani 6800 penerbangan setiap minggu, menerbangkan 1.85 juta ton kargo, dan menghubungkan 320 kota di seluruh dunia (Changi Airport Group, 2016). Dalam industri pariwisata bandara Changi Singapura berfungsi sebagai gerbang bagi negara Singapura untuk menyambut wisatawan. Bandara Changi Singapura secara unik juga merupakan tempat rekreasi bagi penduduk Singapura. Warga Singapura suka membawa keluarganya untuk makan dan berbelanja di bandara karena luas dan dilengkapi penyejuk udara sehingga anak-anak bebas bermain (Church, 2015). Hal ini adalah sesuatu yang unik karena tidak semua bandara di dunia dipandang sebagai tempat rekreasi bagi warganya karena berbagai alasan seperti jarak yang jauh, biaya, serta alasan keamanan dan keselamatan.

Penelitian ini diharapkan dapat memberikan kontribusi pada industri pariwisata dan bandara Changi Singapura dengan menyediakan data mengenai persepsi dan ekspektasi konsumen akan kualitas layanan di area publik terminal 3 bandara Changi Singapura. Studi ini dapat digunakan sebagai salah satu alat evaluasi kinerja bagi pihak manajemen agar dapat memperbaiki kualitas layanan untuk meningkatkan kepuasan konsumen. Pengumpulan data dilakukan untuk mengidentifikasi area yang harus diperbaiki agar bandara Changi mampu memberikan layanan yang lebih baik bagi konsumennya. Area publik terminal 3 bandara Changi Singapura menawarkan berbagai layanan yang termasuk aneka retails dan layanan makanan dan minuman. Sebagai bagian dari pemasukan non aeronautical, retails dan layanan makanan dan minuman merupakan sumber pemasukan terbesar bagi bandara Changi Singapura. Tujuan dari penelitian ini adalah untuk menganalisa tingkat kepuasan konsumen pada area publik terminal 3 bandara Changi Singapura. Untuk mencapai tujuan ini terdapat tiga hal yang harus dilakukan yakni:

1. Investigasi apakah terdapat gap antara ekspektasi dan persepsi konsumen akan kualitas layanan di area publik terminal 3 bandara Changi Singapura.

2. Identifikasi faktor yang mempengaruhi ekspektasi konsumen akan kualitas layanan di area publik terminal 3 bandara Changi Singapura.

3. Identifikasi faktor signifikan yang mempengaruhi persepsi konsumen akan kualitas layanan di area publik terminal 3 bandara Changi Singapura.

Penelitian ini akan mengisi gap penelitian mengenai bandara karena penelitian sebelumnya kebanyakan mengenai privatisasi dan efisiensi bandara. Sedangkan studi mengenai kepuasan konsumen pada industri penerbangan kebanyakan berkaitan dengan maskapai penerbangan saja. Hanya ada beberapa studi mengenai kepuasan konsumen di bandara. Berikut beberapa studi mengenai bandara dan kepuasan konsumen pada konteks bandara dan maskapai:

Studi oleh Marques dan Barros (2011) menganalisa regulasi kepemilikan dan kemampuan manajerial sebagai factor yang mempengaruhi kinerja perwakilan bandara di Eropa sebagai sampel penelitian. Ranking bandara diurutkan berdasarkan efisiensi teknis pada periode tahun 2001 hingga tahun 2004. Variable homogen dan heterogen dijabarkan kedalam fungsi biaya yang mengarah pada saran untuk implementasi kebijakan umum dan kebijakan berdasarkan segmen. Studi oleh De Meyer dan Mostert (2011) mengenai pengaruh kepuasan konsumen pada pembentukan hubungan pada konteks industry penerbangan domestik di Afrika Selatan. Hasil penelitian menunjukkan jika penumpang yang puas dengan layanan dalam penerbangan telah membentuk hubungan dengan maskapai penerbangan 
domestik yang paling sering mereka gunakan. Kepuasan konsumen penting agar perusahaan tetap kompetitif. Studi ini membantu menyediakan pemahaman antara kepuasan konsumen dan pembentukan hubungan antara penumpang dengan industry penerbangan domestik di Afrika Selatan. Studi oleh Curry dan Gao (2012) fokus kepada hubungan antara kualitas layanan, kepuasan konsumen dan loyalitas pada konteks maskapai penerbangan berbiaya rendah. Hasil dari penelitian ini menunjukkan jika kualitas layanan dan kepuasan konsumen memiliki dampak positif pada niat pembelian kembali. Kepuasan konsumen adalah pendorong yang lebih kuat dalam mempengaruhi loyalitas pembelian kembali. Hal ini mengindikasikan jika kedua konstruk dalam penelitian ini berinteraksi dalam cara yang berbeda pada konteks maskapai berbiaya rendah. Studi oleh Ha et al. (2010) secara empiris mengevaluasi level dan perubahan efisiensi (produktivitas) di beberapa bandara di Asia Timur yakni: Tokyo (Narita), Osaka (Kansai), Seoul (Incheon dan Gimpo), Beijing, Shanghai, Guangzhou, dan Hong Kong. Data Envelopment Analysis (DEA) digunakan untuk menganalisa data tahun 1994-2007. Peneliti menemukan jika semua sampel bandara telah memiliki peningkatan dalam produktivitas pada periode sampel tersebut. Namun di lain pihak tidak ada bandara dalam sampel yang mengalami perbaikan produktivitas yang konsisten. Untuk memperbaiki produktivitas bandara di Asia Timur maka diperlukan revolusi teknologi pada level industry dan perbaikan teknis seperti manajemen bandara yang lebih baik. Berdasarkan uraian diatas penelitian ini dilakukan untuk mengisi gap penelitian sebelumnya yang masih belum banyak mengungkap mengenai kepuasan konsumen akan kualitas layanan pada konteks bandara. Dari beberapa penelitian diatas dapat dilihat jika hanya ada beberapa studi yang fokus menganalisa kepuasan konsumen pada konteks bandara.

Penelitian ini bertujuan untuk menganalisa kualitas layanan menurut pandangan konsumen dengan menggunakan SERVQUAL dengan mengukur gap antara persepsi dan ekspektasi konsumen akan kualitas layanan di area publik terminal 3 bandara Changi Singapura. Untuk mencapai tujuan penelitian maka terdapat tiga hal yang perlu dinvestigasi yakni:

- Gap antara ekspektasi dan harapan konsumen akan kualitas layanan di bandara Changi Singapura area publik terminal 3.

- Identifikasi faktor signifikan yang mempengaruhi ekspektasi konsumen akan kualitas layanan di bandara Changi area publik terminal 3.

- Indentifikasi faktor signifikan yang mempengaruhi persepsi konsumen akan kualitas layanan di bandara Changi area publik terminal 3.

Saat konsumen mengukur kualitas layanan mereka membuat perbandingan antara persepsi dan ekspektasi akan kualitas layanan (Zeithaml, et al., 2006). Jadi pengukuran dari level kepuasan konsumen akan kualitas layanan adalah pengukuran gap antara ekspektasi konsumen dan persepsi konsumen akan kualitas layanan. Konsumen memiliki berbagai tuntutan dalam kualitas layanan, tidak semua sama penting (Zeitahml, et al., 2006). Oleh karena itu penulis mengajukan hipotesis sebagai berikut:

Hipotesis:

H1: Terdapat gap antara ekspektasi konsumen dan persepsi konsumen akan kualitas layanan di bandara Changi area publik terminal 3.

H2: Terdapat internal consistency dan reliabilitas pada variable yang digunakan untuk melakukan faktor analysis yang focus pada ekspektasi konsumen pada kualitas layanan pada bandara Changi area publik terminal 3.

H3: Terdapat internal consistency dan reliabilitas pada variable yang digunakan untuk melakukan faktor analysis yang focus pada persepsi konsumen pada kualitas layanan pada bandara Changi area publik terminal 3 . 


\section{Kualitas Layanan}

Kualitas layanan adalah sebuah konsep yang abstrak dan ambigu berdasarkan eveluasi dari keseluruhan layanan sebagai bagian dari pengamatan jangka Panjang, kualitas layanan berhubungan namun tidak sama dengan kepuasan (Dagger and Lawley, 2003). Wirtz, et al. (2012) mendefinisikan kualitas layanan sebagai sebuah standard kinerja yang secara konsisten mampu memenuhi dan melampaui harapan konsumen (Wirtz, et al., 2012). Zeitahml dan Bitner (1996) mendefinisikan kualitas layanan sebagai layanan yang superior yang setara dengan ekspektasi konsumen (Zeitahml and Bitner, 1996). Dalam penelitian ini kualitas layanan didefinisikan sebagai standard layanan yang tinggi yang akan menghasilkan kepuasan konsumen. Kualitas layanan yang tinggi mampu membawa dampak positif bagi konsumen dan perusahaan penyedia jasa melalui kesetiaan pelanggan dan word of mouth yang positif dari konsumen sehingga mampu menarik konsumen baru. Pengukuran kualitas layanan lebih sulit untuk dilakukan dibandingkan kualitas barang dikarenakan karakteristik layanan yang berbeda dari jasa. Kotler et al. (2014) mendeskripsikan empat karakteristik layanan yang membuatnya berbeda dari produk yang tangible yakni:

1. Intangibility: Layanan tidak dapat dirasakan dengan kelima panca indera sebelum dibeli.

2. Inseparibility: Layanan merupakan interaksi antara penyedia jasa dan konsumen yang tidak dapat dipisahkan.

3. Variability: kualitas layanan bervariasi tergantung penyedia jasa.

4. Perishability: layanan sebagai produk tidak dapat disimpan untuk penjualan dimasa yang akan datang (Kotler, et al., 2014).

\section{Persepsi Konsumen}

Persepsi konsumen adalah penilaian akan layanan yang dialami oleh konsumen yang sangat subjektif, relative, dinamis dan bervariasi berdasarkan budaya dan kepercayaan yang berbeda (Zeitahml and Bitner, 1996). Kaynak dan Herbig (2013) menyebutkan jika pengukuran kualitas layanan berdasarkan persepsi konsumen sulit dilakukan karena karakteristik layanan yakni intangible (Kaynak and Herbig, 2013). Karakteristik layanan yang lain yang membuatnya sulit untuk diukur adlaah inseparability, konsumen biasanya terlibat dalam proses produksi dan pelaksanaan layanan sehingga akan mempengaruhi kinerja dan kualitas layanan (Wirtz, et al., 2012).

\section{Ekspektasi Konsumen}

Ekspektasi konsumen adalah standar yang berfungsi sebagai dasar penilaian bagaimana layanan seharusnya dilakukan (Zeitahml et al., 2006). Ekspektasi konsumen akan kualitas adalah antisipasi konsumen terhadap sebuah produk atau layanan sedangkan persepsi konsumen akan kualitas adalah konsep subjektif yakni kualitas dinilai berdasarkan persepsi individu yang berbeda-beda satu dengan yang lainnya (Arnould, et al., 2005).

\section{SERVQUAL}

SERVQUAL adalah sebuah model yang diajukan oleh Parasuraman et al. (1988) yang dapat digunakan untuk mengukur ekspektasi dan persepsi konsumen mengenai kualitas layanan, yang terdiri dari 5 dimensi dengan 22 skala poin pengukuran (Parasuraman et al., 1988):

1. Tangibles: fasilitas fisik, peralatan, dan penampilan karyawan.

2. Reliability: kemampuan karyawan untuk melakukan pekerjaan dengan bertanggung jawab dan akurat. 
3. Responsiveness: kemampuan untuk menyediakan layanan dengan segera kepada konsumen.

4. Assurance: pengetahuan karyawan, kesopanan dan kemampuan untuk mendapatkan kepercayaan dari konsumen.

5. Empathy: peduli dan memberikan perhatian secara individu kepada konsumen.

Meskipun model SERVQUAL diciptakan lebih dari 30 tahun lalu, namun SERVQUAL masih banyak digunakan oleh peneliti untuk meneliti kualitas layanan meskipun tidak sedikit pula yang mengkritik. Wang et al. (2015) melakukan telaah pustaka terhadap 367 penelitian yang menggunakan SERVQUAL dari tahun 1988 hingga 2013 dengan lonjakan penggunaan model SERVQUAL yang terjadi pada tahun 20092011 dan menyimpulkan bahwa studi yang menggunakan SERVQUAL dilatarbelakangi oleh pertumbuhan ekonomi, kebijakan pemerintah dan strategi (Wang et al., 2015). Jiang et al (2002) menyimpulkan jika SERVQUAL telah mendemonstrasikan kegunaannya sebagai alat dignosa pada industry jasa secara umum dengan minimal isu terkait reliabilitas dan validitasnya (Jiang et al., 2002). Dalam studi oleh Ruiqi dan Pritchard (2009) SERVQUAL terbukti sebagai instrument yang valid dan reliabel untuk mengukur kualitas layanan dari agen perjalanan di Guangzhou China. Hasil dari studi sejalan dengan meningkatnya keluhan terhadap agen perjalanan berdasarkan data statistik yang disediakan oleh Asosiasi Konsumen di China (Ruiqi and Pritchard, 2009). SERVQUAL juga dapat digunakan untuk mengukur kualitas layanan dan kepuasan konsumen pada perusahaan asuransi kendaraan di Austria (Burböck, 2014). Pada studi Vijayvargy (2014) SERVQUAL digunakan untuk mengukur kualitas layanan di restaurant cepat saji di Jaipur India. SERVQUAL juga dapat digunakan untuk mengukur kepuasan konsumen dan kualitas layanan pada industry perbankan di India (Ishaan, et al., 2015). Beberapa studi yang telah disebutkan membuktikan bahwa SERVQUAL merupakan model yang fleksibel dan robust yang dapat digunakan untuk mengukur kepuasan konsumen dan kualitas layanan pada berbagai industry.

Dalam studi oleh Anca (2014) SERVQUAL digunakan untuk menilai kualitas layanan pada hotel Athenee Palace Hilton di Bucharest. Studi ini focus pada kinerja karyawan hotel sebagai penyedia jasa. 5 dimensi SERVQUAL dimodifikasi untuk mengukur ekspektasi dan persepsi konsumen akan karyawan hotel Athenee, sebagai contoh dalam dimensi tangible disesuaikan dengan perilaku karyawan, bagaimana seharusnya karyawan bertindak, mengenakan busana yang sesuai dan mendapatkan pelatihan mengenai layanan (Anca, 2014). Hal ini menunjukkan jika model SERVQUAL dapat dimodifikasi dan disesuaikan untuk mengukur berbagai aspek layanan. Aplikabilitas 5 dimensi orginal SERVQUAL dikritik oleh Lee (2005). SERVQUAL digunakan untuk mengukur kualitas layanan dalam konteks kesehatan di Ukraina. Data analisis yang dilakukan dalam studi ini mendemonstrasikan hanya 4 dimensi SERVQUAL yang dapat diaplikasikan. Peneliti menyimpulkan jika kesulitan dalam pengukuran kualitas layanan terjadi karena adanya faktor budaya. Dimensi tertentu yang nampak penting pada suatu negara belum tentu penting pada konteks layanan pada negara lain (Lee, 2005). Studi oleh Souca (2012) menggunakan SERVQUAL untuk investigasi persepsi kualitas dan kepuasan konsumen pada industri hospitalitas di Romania. Studi ini menggunakan 11 aspekyang dikelompokkan menjadi tiga dimensi yakni: responsiveness, reliability, dan tangible. Dalam studi oleh Marincovic et al. (2013), SERVQUAL dengan sedikit modifikasi digunakan untuk mengevaluasi level kepuasan konsumen terhadap agen perjalanan di Serbia. Menurut mereka empat dimensi SERVQUAL (tangibility, responsiveness, reliability, dan emphaty) adalah faktor yang paling penting dalam meningkatkan kepuasan konsumen. Studi oleh Marinescu dan Ispas (2012), SERVQUAL digunakan pada industry hotel karena dapat menyediakan deskripsi mendetail tentang persepsi dan ekspektasi konsumen sehingga data dapat digunakan untuk mengutamakan area yang perlu diperbaiki. Marinescu dan Ispas (2012) menyatakan jika model SERVQUAL yang menggunakan 5 dimensi tidak universal sehingga modifikasi diperlukan. Menurut Parasuraman et al. (1988) SERVQUAL adalah kerangka kerja mendasar yang dapat dimodifikasi saat diperlukan tergantung pada konteksnya. SERVQUAL yang sudah 
dimodifikasi dapat digunakan pada berbagai industry jasa seperti hotel, transportasi, agen perjalanan, dan perbankan.

\section{B. METODE PENELITIAN}

Penelitian ini menggunakan pendekatan kuantitatif yang bersifat deskriptif karena tujuan penelitian ini adalah untuk mengukur kepuasan konsumen terhadap kualitas layanan. Penelitian deskriptif dimulai dengan menjelaskan subjek penelitian dengan jelas dan diikuti dengan elaborasi mendetail mengenai penelitian untuk menggambarkan penelitian secara jelas (Neuman, 2007). Situasi atau fenomena dapat dijelaskan secara akurat dengan menggunakan pendekatan deskriptif (Johnson and Christensen, 2010). Penelitian ini digunakan untuk menjelaskan kepuasan konsumen pada kualitas layanan di area publik terminal 3 bandara Changi Singapura. Data primer penelitian ini dikumpulkan melalui survei menggunakan kuesioner dengan 5 skala Likert. Kuesioner berisi 4 dimensi dari SERVQUAL yakni tangible, reliability, responsiveness dan assurance. Alasan mengapa hanya 4 dimensi SERVQUAL digunakan pada penelitian ini adalah karena area publik terminal 3 bandara Changi merupakan sebuah tempat yang mengakomodir beragam penyewa yang menawarkan berbagai layanan tidak hanya terbatas pada retail dan F\&B namun juga penukaran uang, kantor pos dan tempat bermain anak. Dimensi kelima SERVQUAL yakni emphaty dapat diartikan sebagai personalisasi layanan dari karyawan. Penelitian ini focus kepada kepuasan konsumen akan kualitas layanan di area publik terminal 3 bandara Changi yang merupakan tempat heterogen dimana terdapat bauran antara karyawan bandara Changi dan karyawan toko sehingga dimensi empathy tidak dimasukkan ke dalam penelitian ini.

Populasi penelitian ini adalah warga Singapura yang berada di area publik terminal 3 bandara Changi yang datang untuk tujuan rekreasi dan mengantar teman atau anggota keluarga mereka yang berpergian. Neuman (2007) menyebutkan bahwa saat ukuran populasi diatas 10 juta maka sampling rasio tidak lagi relevant. Ukuran sampel sekitar 2500 adalah sama akuratnya untuk populasi 10 juta hingga 200 juta. Sampling rasio menurun saat ukuran populasi meningkat (Neuman, 2007). Berdasarkan data statistik oleh pemerintah Singapura, total populasi di Singapura pada tahun 2015 adalah 5.535.000 (Government of Singapore, 2015). Berdasarkan Neuman sampling rasio 1\% dari total populasi adalah 5.535 adalah jumlah yanga sangat besar untuk studi ini, maka total 250 survei kuesioner disebarkan berdasarkan justifikasi peneliti karena keterbatasan waktu, biaya, dan sumber daya manusia.

Partisipan dari survei adalah warga Singapura berusia 18-60 tahun, wisatawan yang mengunjungi Singapura tidak termasuk sampel dari penelitian. Area publik di bandara Changi Singapura terminal 3 adalah area yang dapat diakses oleh publik tanpa harus menunjukkan boarding pass. Area ini meliputi basement 2 yang menawarkan berbagai retail dan kedai makanan dan minuman serta supermarket, basement 1 dan area kedatangan serta keberangkatan dimana terdapat convenience store, penukaran uang, café dan kedai makan dan minum, kantor pos, dan restaurant keluarga (Changi Airport Group, 2016). Bandara Changi Singapura mampu menarik banyak konsumen karena menawarkan keuntungan bagi konsumen termasuk keanggotaan Changi Reward Membership yang menawarkan promosi menarik dan belanja bebas pajak (Changi Airport Group, 2016). Bandara Changi Singapura juga mudah diakses dengan berbagai sarana transportasi publik termasuk taksi, bis dan mrt (mass rapid transportation).

Penelitian ini menggunakan Teknik sampling non-probabilitas karena kuesioner didistribusikan berdasarkan kesediaan partisipan untuk mengisi kuesioner. Meskipun data yang dihasilkan dari teknik sampling ini terbatas, namun data masih dapat mewakili populasi dengan baik apabila pengumpulan data dijelaskan secara rinci dan analisis dilakukan dengan benar. Untuk memperbaiki kualitas dan akurasi nonprobabilitas sampling, proses pengambilan sampel dan partisipan harus didefinisikan dengan jelas (Gravetter dan Forzano, 2011). 
Kuesioner berisi pertanyaan mengenai empat dimensi SERVQUAL untuk mengukur kepuasan konsumen akan kualitas layanan digunakan sebagai instrument penelitian. Daftar pertanyaan pada kuesioner dapat dilihat pada lampiran. Kuesioner pada penelitian ini menggunakan empat dimensi SERVQUAL yakni: tangible, reliability, responsiveness, dan assurance karena area publik terminal 3 bandara Changi Singapura adalah sebuah tempat yang mengakomodasi klaster penyewa yang menawarkan beragam layanan seperti retail, restoran, jasa penukaran uang, kantor pos dan area bermain anak. Dimensi kelima SERVQUAL adalah empathy yang dapat diartikan sebagai personalisasi layanan oleh penyedia layanan. Penelitian ini fokus pada kepuasan konsumen akan kualitas layanan di area publik terminal 3 bandara Changi Singapura secara umum bukan pada toko tertentu di bandara Changi Singapura sehingga aspek emphaty tidak dimasukkan ke dalam studi ini. Kuesioner terbagi menjadi tiga bagian, bagian pertama adalah pertanyaan mengenai profil demografi berrisi usia, jenis kelamin, pekerjaan, dan status pernikahan. Bagian kedua berisi 20 pertanyaan mengenai ekspektasi kosumen akan kualitas layanan di area publik bandara Changi Singapura terminal 3. Bagian ketiga berisi 20 pertanyaan mengenai persepsi kosumen akan kualitas layanan di area publik bandara Changi Singapura terminal 3. Partisipan diminta mengisi jawaban mereka menggunakan skala Likert karena respon partisipan dapat dikuantifikasi dengan menggunakan pendekatan ini (Veal, 2011).

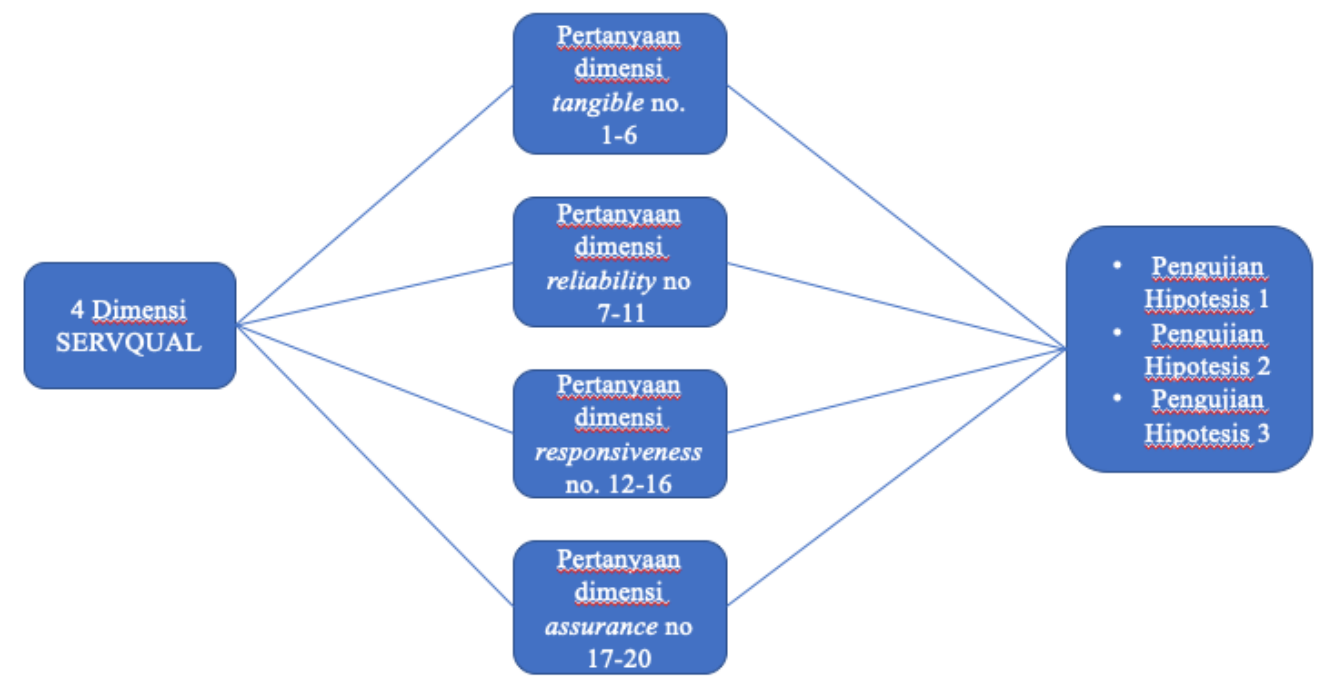

Gambar 1. Rancangan Design Kuesioner

Pengumpulan data dilakukan selama kurang lebih 4 minggu di area publik bandara Changi Singapura terminal 3 dengan mendekati partisipan untuk meminta kesediaan mereka mengisi kuesioner.Sebanyak 250 kuesioner didistribusikan kepada responden. Dari 250 kuesioner, terdapat 14 kuesioner yang tidak dapat digunakan sehingga terdapat sebanyak 236 kuesioner yang dapat digunakan untuk analisa data.

\section{HASIL DAN ANALISIS}

Sebanyak 236 kuesioner yang dapat digunakan dianalisa menggunakan SPSS 21. Hanya data yang valid tanpa missing value yang digunakan dalam analisa statistik yang termasuk:

1. Uji Cronbach's Alpha untuk pengukuran internal konsistensi (Harmon, 2011) 
2. Uji sampel $t$-test berpasangan untuk membuat dua perbandingan antara dua sampel yang dipasangkan pada sekelompok orang yang sama (persepsi dan ekspektasi) (Macdonald, 2015).

3. Uji KMO untuk mengukur korelasi variable (Elliot and Woodward, 2014)

4. Bartlett test of Sphericity untuk pengujian hipotesis (Elliott and Woodward, 2014)

5. Faktor analysis untuk memutuskan variasi dan jumlah faktor latent variable (Brown, 2015)

Sebelum melakukan faktor analisis, skala reliabiltas digunakan untuk mengetahui adanya internal consistency dari variable untuk digunakan pada analisa faktor. Reliabilitas berarti dapat diduplikasi yakni pengukuran akan menghasilkan hasil secara konsisten secara terus menerus sehingga disebut reliabel. Reliabilitas sebuah instrument menempatkan batas atas dari validitas. Pengukuran yang tidak reliabel maka tidak memiliki validitas (Naik dan Srinivasan, 2015). Cronbach alpha didesign untuk mengukur internal consistency (Harmon, 2011). Alpha diukur dalam skala yang sama dengan (r) Pearson correlation coefficient yang memiliki skala pengukuran antara 0 sampai 1, makin dekat nilai alpha ke 1 maka makin besar internal consistency (Naik dan Srinivasan, 2015).

Sebanyak 56\% responden adalah perempuan dan 44\% laki-laki yang merupakan representasi yang cukup baik pada sampel kedua gender. Sebanyak $32 \%$ responden berusia antara 30-40 tahun, diikuti dengan $26 \%$ berusia $40-50$ tahun, $24 \%$ responden berusia $50-60$ tahun, dan $18 \%$ responden berusia $18-$ 30 tahun. Hal ini mengindikasikan jika pengunjung area publik bandara Changi Singapura berasal dari beragam rentang usia sehingga sebaiknya fasilitas dan toko yang ada didedikasikan untuk konsumen segala usia. Tingkat Pendidikan paling besar adalah sarjana sebanyak $46 \%$, sekolah menengah atas $30 \%$, pasca sarjana $24 \%$. Sebanyak $58 \%$ responden menikah dan $42 \%$ responden tidak menikah. Sebanyak $40 \%$ responden membawa anak dan sebanyak $60 \%$ tidak membawa anak.

\begin{tabular}{|l|c|c|c|c|c|c|c|}
\hline \multirow{2}{*}{ Pertanyaan } & \multicolumn{2}{|c|}{ Ekspektasi } & \multicolumn{2}{c|}{ Persepsi } & Gap & t-value & $\begin{array}{c}2 \\
\text { tailed } \\
\text { t-test }\end{array}$ \\
\cline { 2 - 8 } & Mean & SD & Mean & SD & & & \\
\hline 1. Suasana & 4.87 & .330 & 4.85 & .367 & -0.02 & .544 & .587 \\
\hline 2. Keluasan & 4.85 & .356 & 4.80 & .406 & -0.05 & 1.593 & .112 \\
\hline 3. Fasilitas bekerja & 4.63 & .483 & 4.43 & .505 & -0.20 & 5.735 & $\mathbf{. 0 0 0}$ \\
\hline 4. Penampilan karyawan & 4.23 & .446 & 4.00 & .406 & -0.23 & 5.976 & $\mathbf{. 0 0 0}$ \\
\hline 5. Nomor telepon darurat & 3.99 & .600 & 2.64 & 1.196 & -1.35 & 16.490 & $\mathbf{. 0 0 0}$ \\
\hline $\begin{array}{l}\text { 6. Ketersediaan toko dan } \\
\text { restoran }\end{array}$ & 4.25 & .507 & 4.15 & .492 & -0.10 & 2.930 & $\mathbf{. 0 0 4}$ \\
\hline 7. Fasilitas untuk anak & 4.19 & .448 & 4.12 & .429 & -0.07 & 2.587 & $\mathbf{. 0 1 0}$ \\
\hline 8. Ruang laktasi & 4.12 & .469 & 3.86 & .511 & -0.26 & 6.888 & $\mathbf{. 0 0 0}$ \\
\hline $\begin{array}{l}\text { 9. Dapat diakses kursi } \\
\text { roda }\end{array}$ & 4.33 & .497 & 4.35 & .529 & 0.02 & -3.11 & .756 \\
\hline
\end{tabular}

86 | Barista: Jurnal Kajian Bahasa dan Pariwisata, Volume 6 Nomor 2, 2019: 79-92 


\begin{tabular}{|c|c|c|c|c|c|c|c|}
\hline $\begin{array}{l}\text { 10. Ketepatan shuttle bus } \\
\text { dan sky train }\end{array}$ & 4.39 & .514 & 4.36 & .507 & -0.03 & .843 & .400 \\
\hline 11. Ketersediaan klinik & 4.17 & .414 & 3.78 & .657 & -0.39 & 7.078 & .000 \\
\hline 12. Pusat informasi & 4.11 & .440 & 3.91 & .505 & -0.20 & 4.967 & .000 \\
\hline $\begin{array}{l}\text { 13. Ketersediaan multi } \\
\text { media }\end{array}$ & 4.07 & .463 & 3.86 & .543 & -0.21 & 4.636 & .000 \\
\hline 14. Lost and Found & 4.16 & .417 & 3.91 & .484 & -0.25 & 6.102 & .000 \\
\hline 15. Call Center & 3.70 & .683 & 3.10 & .628 & -0.60 & 9.867 & .000 \\
\hline 16. Tanggap kebersihan & 4.18 & .436 & 4.23 & .452 & 0.05 & -1.173 & .242 \\
\hline $\begin{array}{l}\text { 17. Pilihan toko dan } \\
\text { barang yang dijual }\end{array}$ & 4.27 & .500 & 4.20 & .545 & -0.07 & 2.005 & .046 \\
\hline 18. Keamanan transaksi & 4.58 & .493 & 4.67 & .470 & 0.09 & 10.128 & .000 \\
\hline $\begin{array}{l}\text { 19. Karyawan yang } \\
\text { sopan dan tidak } \\
\text { mendiskriminasi }\end{array}$ & 4.54 & .498 & 3.37 & .872 & -1.19 & -3.406 & .001 \\
\hline $\begin{array}{l}\text { 20. Keamanan dan } \\
\text { keselamatan }\end{array}$ & 4.79 & .405 & 4.79 & .405 & 0 & -1.37 & .891 \\
\hline $\begin{array}{l}\text { Total Mean untuk } 20 \\
\text { pertanyaan }\end{array}$ & 4.321 & & 4.069 & & -5.03 & & \\
\hline
\end{tabular}

Tabel 1 Hasil Uji Statistik

Berdasarkan hasil analisa deskripsi statistik pada tabel 1, dapat dilihat jika ekpektasi dan persepsi konsumen tertinggi terdapat pada suasana dan keluasan yang merupakan bagian dari dimensi tangible, diikuti keamanan dan keselamatan yang merupakan bagian dari dimensi assurance. Tabel hasil deskripsi statistik terdapat pada lampiran. Ekspektasi terendah ada pada aspek nomor telepon darurat dan call center. Persepsi terendah juga ada pada kedua aspek tersebut serta aspek karyawan yang sopan dan tidak diskriminatif. Terdapat empat positive gap yakni dapat diakses kursi roda, tanggap kebersihan, keamanan transaksi dan aspek keamanan dan keselamatan.

\section{Two tailed t test}

Two tailed t-test digunakan untuk melakukan verifikasi gap pada mean variable ekspektasi dan variable persepsi apakah benar-benar berbeda atau terjadi karena kebetulan (Harmon, 2011). Level signifikansi untuk regresi analisis pada penelitian social adalah 5\% (alpha value:0.05) dengan level kepercayaan 95\% (Morien, 2007). Dalam penelitian ini two tailed t-test dilakukan pada ekspektasi dan persepsi konsumen. Hasil descriptive statistik menunjukkan jika terdapat beberapa aspek yang memiliki nilai p signifikan dan beberapa lainnya memiliki nilai p tidak signifikan. 
Pengujian Hipotesis 1

H1: Terdapat gap antara ekspektasi konsumen dan persepsi konsumen akan kualitas layanan di bandara Changi area publik terminal 3.

Dari table 1 terdapat gap antara ekspektasi dan persepsi konsumen. Oleh karena itu hipotesis 1 didukung. Gap negative berarti persepsi konsumen akan kualitas layanan lebih rendah daripada ekspektasi konsumen.

Pengujian Hipotesis 2

H2: Terdapat internal consistency dan reliabiliatas pada variable yang digunakan untuk melakukan faktor analysis yang fokus pada ekspektasi konsumen pada kualitas layanan pada bandara Changi area publik terminal 3. Dari table dapat dilihat nilai Cronbach's Alpha adala 0.829 yang berarti variable memiliki internal consistency yang tinggi sehingga faktor analisis dapat dilakukan. Oleh karena itu H2 didukung.

\begin{tabular}{|c|c|c|}
\hline Cronbach's Alpha & $\begin{array}{c}\text { Cronbach's Alpha Based on } \\
\text { Standardize items }\end{array}$ & N of items \\
\hline .829 & .834 & 20 \\
\hline
\end{tabular}

Tabel 2. Nilai Cronbach's Alpha Ekspektasi Konsumen

\begin{tabular}{|r|l|}
\hline Kaiser-Meyer-Olkin Measure of Sampling Adequacy & .793 \\
Approx of Chi-Square & 1593.087 \\
Bartlett's Test of Sphericity df & 190 \\
sig & .000 \\
\hline
\end{tabular}

Tabel 3. Nilai KMO Ekspektasi Konsumen

KMO (Kaiser-Meyer-Olkin Measure of Sampling Adequacy) digunakan untuk menguji korelasi antar variable. Nilai KMO harus diatas 0.5 untuk faktor analisis yang memuaskan, makin tinggi nilai KMO makin baik (Hinton, 2014). Dari table dapat dilihat jika nilai KMO adalah .793 yang berarti semua variable berkorelasi secara signifikan. Setelah dilakukan rotasi varimax terdapat 5 faktor pembentuk ekspektasi konsumen berdasarkan nilai signifikan loading setiap fakor yang terkumpul kedalam komponen yang sama ditentukan yakni jaminan dan keamanan, kenyamanan dan kemudahan, keselamatan dan layanan, suasana, dan aksesibilitas. Tabel rotasi varimax dan pengelompokan faktor dapat dilihat di lampiran.

Rotasi varimax adalah rotasi orthogonal yang umum digunakan pada ilmu social, rotasi dilakukan pada faktor solusi untuk identifikasi faktor signifikan dari data yang diinginkan (O'Rourke \& Hatcher, 2013). Berikut adalah langkah untuk interpretasi hasil rotasi varimax (O'Rourke \& Hatcher, 2013):

- Identifikasi data dengan nilai loading yang tinggi (lebih tinggi dari 0.4) dalam setiap barisan.

- Variable dengan nilai loading tinggi dalam lebih dari satu faktor dapat diabaikan.

- Ulangi proses untuk variable lainnya.

- Review variable lainnya dengan nilai loading signifikan untuk menganalisa kesamaan dalam tiap faktor untuk menamai ulang faktor tersebut.

Keputusan untuk menamai ulang faktor adalah subjektif bergantung pada justifikasi peneliti untuk dapat membuat faktor lebih bermakna (Ho , 2006). 


\section{Pengujian Hipotesis 3}

H3: Terdapat internal consistency dan reliabilitas pada variable yang digunakan untuk melakukan faktor analysis yang focus pada persepsi konsumen pada kualitas layanan pada bandara Changi area publik terminal 3.

\begin{tabular}{|c|c|c|}
\hline Cronbach's Alpha & $\begin{array}{c}\text { Cronbach's Alpha } \\
\text { Based on Standardize } \\
\text { items }\end{array}$ & N of items \\
\hline .690 & .726 & 20 \\
\hline
\end{tabular}

\section{Tabel 4. Nilai Cronbach Alpha Persepsi Konsumen}

Dari table 4, pengujian nilai Cronbach's Alpha 690 sedikit dibawah nilai Cronbach's Alphayang baik yakni .70. Hal ini dapat terjadi karena jawaban dari partisipan yang kurang konsisten. Nilai alpha yang dibawah standard dapat juga disebabkan salah satu aspek yang tidak reliabel (Garson, 2001). Prosedur analisa faktor harus dilakukan untuk mengidentifikasi aspek yang tidak reliabel (Ho, 2006). Setelah dilakukan iterasi dengan menghilangkan satu persatu aspek dan menghitung nilai Cronbach's Alpha seperti yang disarankan oleh Garson (2001), ditemukan bahwa setelah aspek kelima dihilangkan maka nilai alpha meningkat secara signifikan. Tabel hasil analisa faktor dapat di lihat di tabel 5.

\begin{tabular}{|c|l|}
\hline Kaiser-Meyer-Olkin Measure of Sampling Adequacy & .785 \\
Approx of Chi-Square & 1323.612 \\
Bartlett's Test of Sphericity df & 190 \\
sig & .000 \\
\hline
\end{tabular}

\section{Tabel 5 Nilai KMO Persepsi Konsumen}

KMO (Kaiser-Meyer-Olkin Measure of Sampling Adequacy) digunakan untuk menguji korelasi antar variable. Nilai KMO harus diatas 0.5 untuk faktor analisis yang memuaskan, makin tinggi nilai KMO makin baik (Hinton, 2014). Nilai KMO adalah 0.785 Signfikansi nilai Bartlett's Test of Sphericity adalah 0.000 , nilai yang lebih kecil dari 0.5 mengindikasikan hubungan yang signifikan antar variable. Setelah dilakukan rotasi varimax dapat disimpulkan jika persepsi konsumen ditentukan oleh 6 faktor berdasarkan nilai signifikansi loading setiap faktor yang terkumpul kedalam komponen yang sama yakni: kemudahan dan layanan, kenyamanan, suasana dan kebersihan, keamanan, aksesibilitas dan keselamatan. Tabel rotasi varimax dan pengelompokan faktor daftar dilihat di lampiran.

\section{SIMPULAN}

Studi ini menganalisa kepuasan konsumen dengan mengukur ekspektasi dan persepsi konsumen akan kualitas layanan di area publik terminal 3 bandara Changi Singapura dengan menggunakan 4 dimensi SERVQUAL. Penelitian ini juga mengidentifikasi faktor apa saja yang berkontribusi pada ekspektasi dan persepsi konsumen akan kualitas layanan. Berdasarkan temuan penelitian ditemukan gap negative yang mengindikasikan persepsi konsumen akan kualitas layanan adalah lebih rendah daripada ekspektasi konsumen. Gap antar aspek tidaklah sama, hal ini sejalan dengan apa yang ditulis oleh Zeitahml et al. (2006) bahwa tuntutan konsumen terhadap kualitas layanan jatuh pada aspek yang berbeda, tidak semua sama penting (Zeithaml et al., 2006). Hill et al (2003) juga menyebutkan jika pengukuran kepuasan konsumen dapat digunakan untuk mengidentifikasi area mana yang perlu diprioritaskan untuk diperbaiki. Prioritas perbaikan kualitas layanan dapat dibuat berdasarkan seberapa besar gap pada setiap 
pertanyaan. Bagi manajer dan pembuat kebijakan di bandara Changi Singapura informasi ini dapat digunakan untuk membuat kebijakan yang tepat untuk memperbaiki kualitas layanan.

Dari table deskripsi statistik dapat dilihat terdapat gap positive antara persepsi dan ekspektasi konsumen, diantaranya aspek ramah kursi roda, respons terhadap kebersihan, transaksi yang aman, dan tempat yang aman. Hal ini merupakan indikator jika persepsi konsumen akan keempat aspek tersebut melampaui ekspektasi mereka. Konsumen merasa puas dengan keamanan, keselamatan dan kebersihan di bandara Changi. Hal ini sesuai dengan studi oleh Tambyah dan Tan mengenai index kepuasan warga Singapura, kebersihan dan keamanan adalah beberapa aspekyang membuat warga Singapura paling puas (Tambyah dan Tan, 2013).

Sementara terdapat 16 aspek lainnya yang menerima gap negative yakni: suasana, keluasan, fasilitas bekerja dengan baik, penampilan karyawan, nomor telepon darurat, keberadaan toko dan restaurant, fasilitas untuk anak-anak, ruang untuk menyusui, pusat informasi, keberadaan multi media, lost and found, call centre, ragam toko dan barang yang dijual, karyawan yang sopan dan tidak mendikriminasi. Gap negative berarti kualitas layanan berada dibawah ekspektasi konsumen sehingga perbaikan diperlukan.

Gap negative yang paling besar ada pada aspek nomor telepon darurat, hal ini dikarenakan pada saat penelitian dilakukan nomor telepon darurat tidak dipasang ditempat yang dapat dengan mudah dilihat oleh publik. Gap negative terbesar kedua adalah aspek karyawan yang sopan dan tidak mendiskriminasi. Aspek ini memerlukan investigasi lebih lanjut untuk mengetahui perilaku karyawan yang seperti apa yang dianggap tidak sopan atau mendikriminasi oleh konsumen. Untuk memperbaiki performa layanan, pelatihan dalam bidang layanan terhadap karyawan perlu ditingkatkan.

Diantara aspek dengan gap negative terdapat 3 aspek yang memiliki gap sangat kecil diantaranya suasana, keluasan, ketepatan shuttle bus dan sky train. Hal ini konsisten dengan fakta bahwa area publik terminal 3 bandara Changi Singapura memiliki suasana yang menyenangkan dengan langit-langit yang tinggi dan pencahayaan yang baik. Shuttle bus dan sky train juga tersedia dengan ketepatan yang dapat diandalkan. Persepsi konsumen sedikit lebih rendah dari ekspektasi mereka pada ketiga aspek tersebut berarti mereka sudah cukup puas dengan layanan yang mereka terima pada ketiga aspek tersebut, hanya sedikit perbaikan diperlukan.

\section{Keterbatasan Penelitian}

Penelitian ini hanya dilakukan di salah satu terminal di bandara Changi Singapura dengan jumlah sampel terbatas sehingga analisa dan temuan penelitian ini tidak dapat mewakili kualitas layanan di bandara Changi Singapura secara keseluruhan. Penelitian ini dilakukan di bandara Changi Singapura yang dianggap sebagai tempat yang aman untuk konsumen berekreasi. Hal ini tidak dapat digeneralisasi terhadap bandara-bandara lain di dunia yang memiliki imej yang berbeda karena alasan keselamatan, biaya, dan jarak. Penelitian ini menggunakan skala Likert untuk mengukur ekspektasi dan persepsi konsumen terhadap kualitas layanan, penelitian selanjutnya diharapkan menggunakan wawancara mendalam untuk mendapatkan pengetahuan lebih mendalam mengenai area mana yang perlu diperbaiki untuk meningkatkan kepuasan konsumen.

\section{DAFTAR PUSTAKA}

Anca, M., 2014. Hotel Services Quality Assessment Using SERVQUAL Method. Case Study: Athénée Palace Hotel. Bulletin of the Transilvania University of Brasov. Series V: Economic Sciences, 7(2), pp. 71-76.

Arnould, E. J., Price , L. and Zinkhan, G. M., 2005. Consumers. 2nd ed. Singapore: McGraw-Hill/Irwin. Brown, T. A., 2015. Confirmatory Factor Analysis for Applied Research. 2nd ed. New York: Guilford Publications. 
Burböck, B., 2014. Prospect Theory and SERVQUAL. Management (18544-4223), 9(2), pp. 155-168. Cargan, L., 2007. Doing Social Research. illustrated ed. Maryland: Rowman and Littlefield.

Changi Airport Group, 2016. changiairport.com. [Online] Available at: http://www.changiairport.com/corporate/FAQs/changi-airport-group.html [Accessed 31st July 2016].

Church, J., 2015. What's ahead for Singapore's premier air facility?. Business Traveller (Asia-Pacific Edition), October, pp. 30-36.

Curry, N. \& Gao, Y., 2012. Low- Cost Airlines- A New Customer Relationship? An Analysis of Service Quality, Service Satisfaction, and Customer Loyalty in a Low-Cost Setting. Services Marketing Quarterly, April, 33(2), pp. 104-118.

Dagger, T. and Lawley, M., 2003. Service Quality. In: J. R. McColl-Kennedy, ed. Service Marketing: A Managerial Approach. Sydney: John Wiley and Sons Australia, Ltd, pp. 72-100.

De Meyer, C. \& Mostert, P., 2011. The Influence of Passenger Satisfaction on Relationship Formation in the South African Domestic Airlines. South African Journal of Business Management, December, 42(4), pp. 79-87.

Elliott, A. C. \& Woodward, W. A., 2014. IBM SPSS by Example: A Practical Guide to Statistical Data Analysis. 2nd ed. Thousand Oaks: SAGE Publications.

Garson, G. D., 2001. Guide to Writing Empirical Papers, Theses, and Dissertations. illustrated ed. New York: CRC Press.

\begin{tabular}{l} 
Government of Singapore, 2016. statistics/latest-data\#17. [Online] \\
\hline
\end{tabular} Available at: $\quad$ http://www.singstat.gov.sg/statistics/latest-data\#17 [Accessed 2 September 2016].

Gravetter, F. J. and Forzano, L.-A. B., 2011. Research Methods for the Behavioral Sciences. s.l.:Cengage Learning.

Ha, H.-K., Yoshida, Y. \& Zhang, A., 2010. Comparative Analysis of Efficiency for Major Northeast Asia Airports. Transportation Journal, 1 September, 49(4), pp. 9-23.

Harmon, M., 2011.t-Test in Excel - The Excel Statistical Master. Nevada: Mark Harmon.

Hill, N., Roche, G. and Allen, R., 2007. Customer Satisfaction: The Customer Experience Through the Customer's Eyes. illustrated ed. London: Congent Publishing Ltd.

Hinton, P. R., 2014. Statistics Explained. 3rd, revised ed. East Sussex: Routledge.

Ho , R., 2006. Handbook of Univariate and Multivariate Data Analysis and Interpretation with SPSS. illustrated ed. Boca Raton: Taylor and Francis.

IATA, 2016. IATA Annual Review $2016 . \quad$ [Online] Available at: https://www.iata.org/publications/Documents/iata-annual-review-2016.pdf [Accessed 11 August 2016].

Ishaan, S., Shivali and Garg, A., 2015. Service Quality at Punjab National Bank: using SERVQUAL Instrument. Global Journal of Enterprise Information System, 7(1), pp. 72-79.

Jiang , J. J., Gary, K. and Carr, C. L., 2002. Measuring Information System Service Quality: SERVQUAL from the other side. MIS Quarterly, June, 26(2), pp. 145-166.

Johnson, B. and Christensen, L., 2010. Educational Research: Quantitative, Qualitative, and Mixed Methods. 4th ed. California: SAGE.

Kaynak, E. and Herbig, P., 2013. Handbook of Cross-Cultural Marketing. New York: Routledge.

Kotler, P., Bowen, J. T. and Makens, J. C., 2014. Marketing for Hospitality and Tourism. 6th ed. Harlow: Pearson Education Limited.

Lee, J., 2005. Measuring Service Quality in a Medical Setting in a Developing Country: The Applicability of SERVQUAL. Service Marketing Quarterly, 27(2), pp. 1-14.

Macdonald, S., 2015. Essentials of Statistics with SPSS. 2nd ed. s.l.:Lulu.com.

Marinescu, R. C. \& Ispas, R., 2012. Achieving Sustainable Tourism Through Customer Satisfaction. Annals of the Universty of Oradea, Economic Science Series, 21(2), pp. 349-354.

Marinković, V., Senić, V., Konić, M. \& Šapic, S., 2013. Investigating the Impact of SERVQUAL Dimensions on Customer Satisfaction: The Lessons Learnt from Serbian Travel Agencies. International Journal of Tourism Research, Mar/Apr, 15(2), pp. 184-196. 
Marques, R. C. \& Barros, C. P., 2011. Performance of European airports: regulation, ownership, and managerial efficiency. Applied Economis Letters, Jan, 18(1), pp. 29-37.

Morien, D., 2007. Business Statistics. Melbourne: Cengage Learning.

Naik, K. \& Srinivasan, S. R., 2015. An Assessment of Departmental Store Service Effectiveness using a Modified SERVQUAL Approach. Journal of Business \& Retail Management Research, April, 9(2), pp. 27-43.

Neuman, W. L., 2007. Basic of Social Research: Qualitative and Quantitative Approaches. 2nd ed. California: Pearson/Allyn and Bacon.

O'Rourke, N. \& Hatcher, L., 2013. A Step-by-Step Approach to Using SAS for Factor Analysis and Structural Equation Modelling. 2nd ed. Cary: SAS Institute.

Palmer, A., 2005. Principles of Services Marketing. 4th ed. Berkshire: McGraw-Hill Education.

Parasuraman, A., Zeitahml, V. A. and Berry, L. L., 1988. SERVQUAL: A Multiple-Item Scale for Measuring Consumer Perceptions of Service Quality. Journal of Retailing, 64(1), pp. 12-40.

Ruiqi, Z. and Pritchard, A., 2009. Using SERVQUAL to Measure the Service Quality of Travel Agents in Guangzhou, South China. Journal of Services Research, April-September, 9(1), pp. 87-107.

Senguttuvan, P., 2009. Principles of Airport Economics. New Delhi: Excel Books India.

Souca, L., 2012. SERVQUAL and the Romanian hospitality industry: A study. Proceedings of the International Conference Marketing - from Infromation to Decision, December, Volume 5, pp. 462-279.

Tambyah, S. K. and Tan, S. J., 2013. Happiness and Wellbeing: The Singaporean Experience. Oxon: Routledge.

Veal, A. J., 2011. Research Methods for Leisure and Tourism : A Practical Guide. 4th ed. Harlow: Pearson Education Limited.

Vijayvargy, L., 2014. Measuring Service Quality Using SERVQUAL: A Case of Restaurant Chain. International Journal of Management and Innovation, 6(2), pp. 60-72.

Wang, Y. L., Luor, T., Luarn, P. and Lu, H. P., 2015. Contribution and Trend to Quality Research: a Literature Review of SERVQUAL Model from 1998 to 2013. Informatica Economica, 19(1), pp. 34-45.

Wirtz, J., Chew, P. and Lovelock, C., 2012. Essentials of Services Marketing. 2nd ed. Singapore: Pearson Education South Asia Pte Ltd.

Zeitahml, V. A. \& Bitner, M. J., 1996. Services Marketing. 1st ed. s.l.:McGraw-Hill.

Zeitahml, V. A., Bitner, M. J. and Gremler, D. D., 2006. Services Marketing: Integrating Customer Focus Across the Firm. 4th ed. s.l.:McGraw-Hill. 